\title{
SENIORS LEARNING: A GATE IN THE ENTREPRENEURSHIP CONTEXT
}

\author{
Mariza Cândido da Silva, Roberto Lima Ruas and Leticia Oliveira dos Ouros \\ Universidade Nove de Julio, Brazil
}

\begin{abstract}
The challenges in the labor market faced by individuals with 50 years old or older has compulsorily encouraged their transition to entrepreneurship as an alternative. These individuals have several skills, however, these may not be sufficient to develop a new labor activity. The main objective of this article is to characterize the learning paths and skills of these entrepreneurs. For this, we conducted semi-structured interviews with five entrepreneurs from the city of São Paulo. Data were analyzed through content analysis technique, considering the stages of analysis organization, categorization and treatment, inference and interpretation of results. The identified categories included antecedents, similar learning paths and skills. Among the skills, communication with the ecosystem and the need for multiple and constant learning stand out. Theoretical, practical and social contributions emerge from this research. On the other hand, there is a limitation regarding the generalization of the results, pointing to future research with broader samples.
\end{abstract}

\section{KEYWORDS}

Senior Entrepreneurs, Learning Paths, Skills, Age Discrimination

\section{INTRODUCTION}

The learning process of senior entrepreneurs (Figueiredo \& Paiva, 2019) has been little discussed in the academia. Entrepreneurship has been presented as an alternative for seniors to remain financially active and healthy (Kenny \& Rossiter, 2018), however, it is worth discussing how these individuals learn to be entrepreneurs. Therefore, the learning of seniors becomes a gap to be filled and the objective of this article is to characterize the learning trajectories of these individuals seeking to minimize this gap. A reluctant senior entrepreneur (Galbraith \& Latham, 1996) is an individuals who started entrepreneurship at the age of 50 years old (Kautonen, 2008) or once again was pushed out of necessity for entrepreneurship. The skills that these individuals may have sometimes are not sufficient for the development of a new activity in this age.

Andragogy, "the art and science of facilitating adult learning" (Knowles, 1980, p.43), was adopted in this study due to the scarcity of specific studies (Kenny \& Rossiter, 2018) on learning process of senior entrepreneurs (Figueiredo \& Paiva, 2019). According to Rocha (2014), ten andragogical assumptions assume the functions of facilitating, articulating and leading adult learning relationships, inspiring new trajectories and learning strategies in both business and academic fields. Previous studies address entrepreneurial of older individuals (Singh \& DeNoble, 2003), however, the type of previous experience (Weber \& Schaper, 2004) may be unrelated to the new venture, requiring new knowledge from the individuals. Another factor that oscillates between facilitating or hindering the opening of a new business in the age of 50 is financial capital (Singh $\&$ DeNoble, 2003). On one hand, social security income in some cases may turn into an investment (Singh $\&$ DeNoble, 2003). On the other hand the long period of unemployment in old age negatively affects financial and intellectual capital (Kautonen, 2008; Kenny \& Rossiter, 2018) of this individual also forcing new learning.

This article presents contributions to the learning and entrepreneurship literature, especially on reluctant seniors, and intend to point out social and public policy contributions for inclusion of older people in economic and civil societies. 


\section{BACKGROUND}

This section presents a review of previous studies on adult learning, addressing some andragogical assumptions. And presents a synthesis about entrepreneurship, senior entrepreneurship and some characteristics of the reluctant senior entrepreneur.

\subsection{Andragogical Assumptions and Adult Learning}

There is a lack of specific scientific works on the learning precesses of senior entrepreneurs (Kenny \& Rossiter, 2018; Figueiredo \& Paiva, 2019), which makes it difficult to characterize precisely this concept. Thus, we adopted in this theoretical framework the andragogical assumptions (Rocha, 2014) that elucidate how the adult learning process occurs. The concept of andragogy (Knowles, 1980) emerged in the context of educational learning. However, andragogical assumptions can be identified and applied in contexts of practical learning (Rocha, 2014) since adult learning concerns both academic researchers and corporate managers (Rocha, 2014). According to Knowles (1980, page 43), andragogy is defined as "the art and science of facilitating adult learning". Therefore, andragogy can be understood as a model of adult education (Knowles, 1980), pragmatic, without age restriction, flexible and applicable in different contexts, populations and socio-cultural classes (Nogueira, 2004). Andragogy constitutes the figure of the learning facilitator responsible for favouring and guiding the learning process and the responsible adult learner, who is participative and intrinsically motivated to learn (Nogueira, 2004). Considering that the art of entrepreneurship is strongly indicated in previous studies as a skill acquired through practice (Antonello, 2005; Zampier \& Takahashi, 2011), it is understood that the senior entrepreneur assumes eventually both roles (learning and practice) within this process of learning.

Autonomy, humility, initiative, doubts, change of course, contexts, life experience, search, objectivity and added value are the andragogical assumptions that are fundamental in the adult learning relationship (Rocha, 2014). Adult learning does not support the individual as being passive and restricted to the accumulation of information (Knowles, 1980). Therefore, it is essential to have autonomy in order to guarantee the possibility of intervention, achiving changes and questions that are necessary in this adult learning process (Knowles, 1980; Rocha, 2014). Andragogy concept defines humility as an instrument closely linked to the articulation of human actions in the search for conciliation and dialogue in the relationships among the individuals involved in the learning process (Rocha, 2014). In addition, this process should provide growth, identification of limitations, strengths and weaknesses, and an especial ability to listen (Knowles, 1980; Rocha, 2014). From the perspective of andragogy, doubt is an important assumption that promotes reflections, critical analyzes and interventions in the learning process (Rocha, 2014). The change of course is originally linked to the humility of the learning facilitator in the face of knowledge. However, once applied to an autonomous learning process, change of course redirects strategies in the absence of predicted but unrealized results and goals.

The contexts link theories and past experiences with the real implications of adult learning process, directing actions that align learning objectives and goals. From an andragogical perspective, life experience is the way for adults to rebuild their knowledge. However, considering a process of self-learning, it is appropriate to propose that life experience is also aligned with humility. In a situation in which the senior entrepreneur is his or her own learning facilitator, life experience in line with humility can lead to the perception of the right moment to learn new things despite years of experience. Searching is an act that provides different ways of looking at things and the multiple dimensions of the adult learning path, so it is recognized as a foundation for initiative and autonomy. Finally, for adults, learning is valid when it allows practical application in everyday personal and professional life, which leads to learn what really needs to be learned (Knowles, 1980). This fact is also what is relevant in adding value for andragogical perspective.

\subsection{Entrepreneurship and Senior Entrepreneurship}

From the point of view of GEM - Global Entrepreneurship Monitor, entrepreneurship is any attempt by an individual, a group of individuals or established companies to create a business or a new initiative. For Venkataraman (1997, page 120), entrepreneurship represents "the field of study that seeks to understand how opportunities that generate new products and services are discovered, created and explored, by whom and with what consequences". Several studies characterize entrepreneurship as a field of study with multiple dimensions, multifaceted and multidisciplinary, which explains its ramifications in different areas of human and social 
sciences (Zampier \& Takahashi, 2011). Theoretically, entrepreneurship does not include neither a rigid or a standardized structure. The same happens with the entrepreneur who is considered as the heart of the enterprise (Morrison, 1998). For this reasons, this study does not adopt a specific concept of entrepreneurship.

As an alternative for the older individual to make a profit and remain active and included in society (Kenny \& Rossiter, 2018), senior entrepreneurship defined "the beginning of an entrepreneurial activity by people aged fifty or over" (Figueiredo \& Paiva, 2019, page 3). That presents this age group as another multifaceted entrepreneurial context. At first, studies on senior entrepreneurship were aimed at the retiree and the use of life pension (Singh \& DeNoble, 2003), in opening a new business or the use of bridge entrepreneurship to move from dependent work to entrepreneurship (Quinn, 1980). Surely, with the growth in human life expectancy, the rigidity of wages of older people, rules of seniority, and compulsory retirement (Fuchs, 1980), the subject came to be discussed theoretically.

Therefore, these discussions together with discussions about the global economic crisis and the periods of recession introduced the unemployed senior entrepreneur into the landscape of senior entrepreneurship due to changes in work structures and age discrimination (Kautonen, 2008; Kenny \& Rossiter, 2018 ). This way, the benefits of senior entrepreneurship include developing personally and professionally, balancing the professional and family areas and enjoying active aging (Kautonen, 2012). External factors can lead the individual to undertake, such as taking advantage of a business opportunity, as well as internal factors such as the need for survival, recognition, respect and inclusion that can push seniors towards entrepreneurship.

The tendency of 50 years old (or more) individuals is to remain in the dependent labor market for stability (Kautonen, 2008; Kenny \& Rossiter, 2018). However, when facing a long period of unemployment, entrepreneurship ends up being the only alternative (Singh \& DeNoble, 2003). There are three types of senior entrepreneur: 1) the hard worker who always cultivates the desire to undertake but postpones it for lack of time or money; 2) the rational one who understands entrepreneurship as a career opportunity and wealth formation, and 3) the reluctant who has no intention of undertaking but is forced to do so by the lack of an alternative (Galbraith \& Latham, 1996; Singh \& DeNoble, 2003). Considering that last one, we characterize the reluctant senior entrepreneur analyzed in this study.

\subsubsection{Featuring the Reluctant Senior Entrepreneur}

Reluctant senior entrepreneur, in this study, is the individual who started entrepreneurship over 50 years old, once being pushed by necessity for that. This individual sees entrepreneurship as the only alternative for social and professional survival, also for inclusion (Singh \& DeNoble, 2003), being motivated by internal driving factors (Weber \& Schaper, 2004) such as discrimination (Kenny \& Rossiter, 2018), family losses, low self-esteem and devaluation of experience, although not necessarily having previous experience (Kautonen, 2008) in entrepreneurship or dependent work (Păunescu \& Blid, 2017).

\section{METHOD}

This study is qualitative, considering the freedom and autonomy of the researcher's interpretation, despite the understanding that these interpretations must be based on the stories and perceptions of the individuals who transmit the experiences (Creswell, 2010). The study is also guided by an interpretive paradigm based on inductive logic, supporting the importance of subjective meanings. In this sense, a recurring criticism on qualitative research is due to an empiric character and subjectivity and the researcher's involvement (Silveira \& Córdova, 2009). On the other hand, the researcher is the main research instrument of a qualitative study, according to Ludke and André (2011).

We collected data collection using the technique of semi-structured interviews applied to individuals who, being compulsorily pushed towards entrepreneurship, started to undertake at the age of 50 years old or more. According to Boni and Quaresma (2005), the main benefit of the semi-structured interview and the open interview is that these techniques often produce a better sample of the population of interest. The interviews were previously scheduled and carried out via Skype, being transcribed immediately after data collection, and having a research instrument as a conductor (Creswell, 2014). The steps are shown in Table 1. 
Table 1. Research questionnaire for the reluctant senior entrepreneur

\begin{tabular}{|l|}
\hline General aspects \\
\hline 1 - Interview/ Date: \\
\hline 2 - Interviewee's name: \\
\hline 3 - Formation/schooling: \\
\hline 4 - Age: \\
\hline 5 - Age when you started to undertake: \\
\hline 6 - Entrepreneurship segment: \\
\hline 7 - Skype: \\
\hline 8 - WhatsApp: \\
\hline 9 - Company: \\
\hline 10 - Company location: \\
\hline 11 - Employees? Yes ( ) No ( ) How many? ( \\
\hline Questions \\
\hline What factors motivated you to undertake? \\
\hline How did you acquire skills that enabled you to become an entrepreneur? \\
\hline How did you learn to manage the business? \\
\hline How did you acquire knowledge and skills that enabled you to act? \\
\hline How did you identify what need to be learned? \\
\hline Entrepreneurship from 50 years old is ... \\
\hline
\end{tabular}

We performed data analysis procedures using the content analysis technique following the steps of organization of the analysis: categorization and treatment, inference and interpretation of the results (Bardin, 2010; Mazzotti \& Gewandsznajder, 1999). The analysis organization stage (Bardin, 2010; Mazzotti \& Gewandsznajder, 1999) constitution of the profile of reluctant senior entrepreneurs. We organized personal information, assigning a fictitious name to each in order to guarantee data confidentiality previously established between researcher and interviewees. A summary of the results of the first stage can be seen in Table 2 .

Table 2. Results of the analysis organization step

\begin{tabular}{|l|l|l|l|l|}
\hline Nickname & Age & Age/entrepreneur & Gender & Formation (Schooling) \\
\hline Rick & 50 & 50 & Male & Bachelor of Industrial Technological Chemistry \\
\hline Joseph & 57 & 55 & Male & Technologist in Mechanics \\
\hline Soul & 59 & 55 & Male & Bachelor of Social Studies \\
\hline Robert & 59 & 51 & Male & Marketing \\
\hline Tiffany & 67 & 53 & Female & Decorator \\
\hline
\end{tabular}

Source: the authors

The second stage of the content analysis instituted categorization (Bardin, 2010) so that was possible to create some categories that would contribute to the characterization of the learning trajectory of the reluctant senior entrepreneurs in the sample. The results of this stage are summarized in Table 3. The stage of treatment, inference and interpretation of the results (Bardin, 2010; Mazzotti \& Gewandsznajder, 1999) considered the andragogical principles to identify the skills associated and gradually analyze the learning trajectory of these entrepreneurs, seeking to show fundamental skills to become an entrepreneur from the age of 50 years old. This characterization is presented in Figure 1, with P1 being the andragogical assumptions and Hb the skills associated with these.

Table 3. Results of the categorization stage

\begin{tabular}{|l|l|l|}
\hline Nickname & Motivation & Segment \\
\hline Rick & Discrimination/age & Facilities/Sustainable Management \\
\hline Joseph & Discrimination/age & Lean \\
\hline Soul & Discrimination/age & Processes Improvement \\
\hline Robert & Discrimination/age & Hospitality \\
\hline Tiffany & Divorce & Fashion/E-commerce \\
\hline
\end{tabular}

Source: the authors 


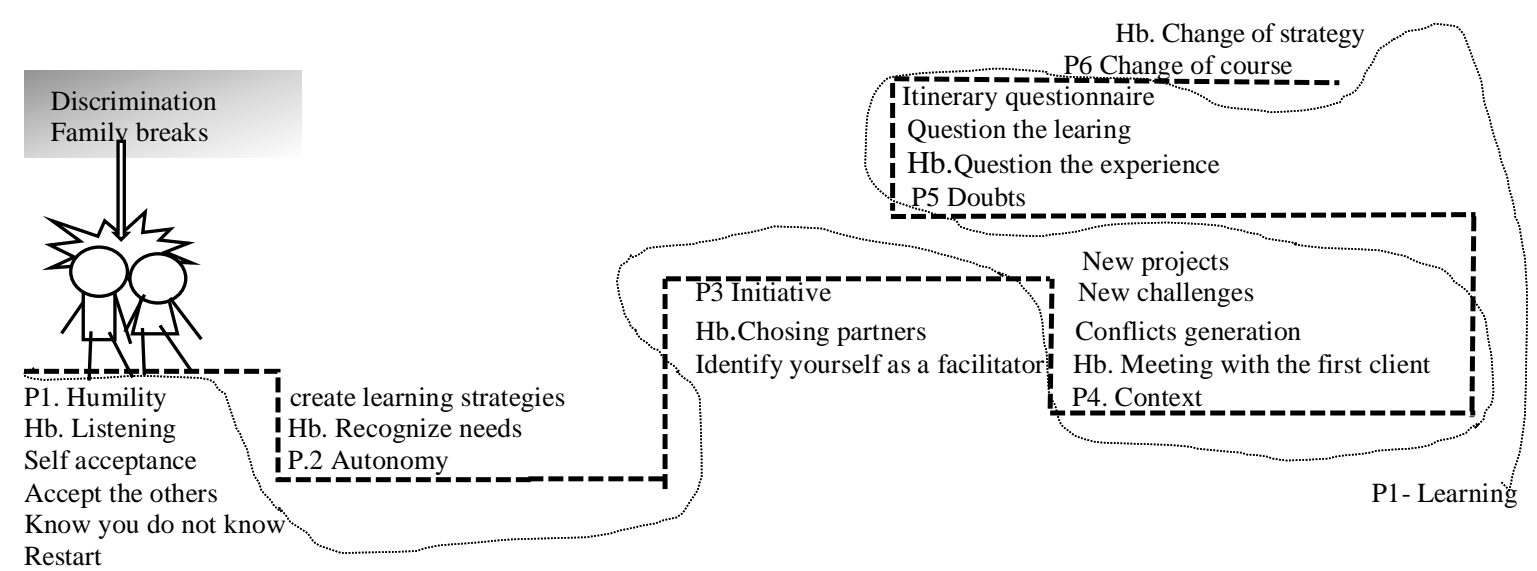

Figure 1. Results - paths of the categorization stage Source: the authors

The treatment step of the analysis, inference and interpretation of results (Bardin, 2010; Mazzotti \& Gewandsznajder, 1999), considered the andragogical principles to identify the skills associated as a starting point for the treatment of the data. In a second step, we associated the other information gradually in order to characterize the trajectory of learning of these entrepreneurs and configure to show main skills to become an entrepreneur after 50 years old. This characterization is shown in Figure 1 and the completion of this stage is detailed in the following results section.

\section{RESULTS}

The results indicate that none of the interviewees explicitly showed the desire to start their own business and that intrinsic factors linked to the need and the lack of alternatives push them towards entrepreneurship. Initial training is not directly linked to current activity, indicating that it is not a planned goal throughout life, but rather the need to reinvent itself in search of financial and personal survival. Age discrimination is a common feeling for all respondents, as well as the devaluation of long-term professional experience and, tacitly this feeling prepares the individuals to lose their current job. However, this facts do not reduce the hope of getting a new opportunity in the labor market until they are pushed towards entrepreneurship. The desire of learning is a common aspect cited among the interviewees, however, the need for what subjects should be learnt arises in the midst of contexts. Also the attempt to undertake, fundamentally demanding principles of humility, autonomy, initiative, context, doubt, and change of course. For the interviewees, humility guides the learning paths of the reluctant senior entrepreneur, and is the way to acquire the ability to listen, accept themselves and recognize the others regardless of age or social position as facilitators of their learning. Rick, Soul, Robert and Tiffany used humility to identify a young person as a essential partner in the search for communication skills, technological tools and market update. On the other hand, for Joseph, the young person hinders a growth as a senior entrepreneur, since young people seduce customers with new ideas and little knowledge and delivery. Joseph perceives the young person as an unfair competitor. Even recognizing that humility is essential in this process of learning, he does not know how to apply it to change his own view on young people and how to perceive them as partners.

Tiffany reports that she chose not to learn how to make the spencer since learning would require valuable time and the results would not have as much output as the expected. Although, she recognizes the importance of added value in her learning trajectory. In Rick's opinion, the change of course is in fact synonymous with inner strength and daring to change strategy. He makes this clear when reports that his biggest challenge was to manage the conflict of generations and, in this context, he chose to ret his rethink leading instead to rely on years of experience. Robert and Soul related similar impressions. For example, when in meetings some clients questioned their experience of years and learnings acquired throughout their lives. These perceptions directed both into critical reflections that allowed them to question their skills and create new solutions to problems previously faced. 


\section{CONCLUSION}

We conclude that the main advantage of this study is that it is one of the firsts on learning activities for reluctant senior entrepreneurs and on the characterization of the learning trajectories of individuals who started in entrepreneurship at the age of 50 or more. Evidence of effective learning strategies and indicators for a change in the learning process can inspire new stories. The small sample used in this study makes it impossible to generalize the results, this being our main limitation in addition to the analysis being carried out in a single economic context. However, future studies can apply this research in other economic, geographic, socio-political contexts. This study is also applicable in other comparative studies of genders or countries looking for similarities, barriers, and advantages in the trajectories of reluctant senior entrepreneurs.

\section{REFERENCES}

Antonello. (2005). A metamorfose da aprendizagem organizacional: Uma revisão crítica. (Aprendizagem organizacional e competências. Porto Alegre: Bookman, 12-33.).

Bardin. (2010). Análise de conteúdo. (Edições 70).

Boni, V., \& Quaresma, S. J. (2005). Aprendendo a entrevistar: Como fazer entrevistas em Ciências Sociais. Em Tese, 2(1), 68-80.

Creswell. (2010). Research design: Qualitative \& quantitative approaches. (Thousand Oaks, Calif. : Sage Publications.).

Creswell. (2014). Research Design: Qualitative, Quantitative, and Mixed Methods Approaches. (SAGE.).

Figueiredo, E., \& Paiva, T. (2019). Senior entrepreneurship and qualified senior unemployment: The case of the Portuguese Northern region. Journal of Small Business and Enterprise Development, 26(3), 342-362.

Fuchs, V. R. (1980). Self-employment and labor force participation of older males (revised). National Bureau of Economic Research Cambridge, Mass., USA.

Galbraith, \& Latham. (1996). Reluctant Entrepreneurs (Frontiers of Entrepreneurial Research, Center for Entrepreneurial Studies, Babson Park.).

Kautonen, T. (2008). Understanding the older entrepreneur: Comparing third age and prime age entrepreneurs in Finland. International Journal of Business Science \& Applied Management (IJBSAM), 3(3), 3-13.

Kautonen, T. (2012). Do age-related social expectations influence entrepreneurial activity in later life? The International Journal of Entrepreneurship and Innovation, 13(3), 179-187.

Kenny, B., \& Rossiter, I. (2018). Transitioning from unemployment to self-employment for over 50s. International Journal of Entrepreneurial Behavior \& Research, 24(1), 234-255.

Knowles, M. S. (1980). The modern practice of adult education.

Ludke, M., \& André, M. E. (2011). Pesquisa em educação: Abordagens qualitativas. Em Aberto, 5(31).

Mazzotti \& Gewandsznajder. (1999). O método nas ciências naturais e sociais. Pesquisa quantitativa e qualitativa. (São Paulo: Pioneira Thomson.).

Morrison. (1998). Entrepreneurship: An international perspective. Oxford: Butterworth-Heinemann, 1998.

Nogueira, S. M. (2004). A andragogia: Que contributos para a prática educativa? Revista Linhas, 5(2).

Păunescu, C., \& Blid, L. (2017). Seniorpreneur as a career option for smart active ageing. A study on Romania. Proceedings of the International Conference on Business Excellence, 11, 826-833.

Quinn, J. F. (1980). Labor-force participation patterns of older self-employed workers. Soc. Sec. Bull., 43, 17.

Rocha, E. F. (2014). Os dez pressupostos andragógicos da aprendizagem do adulto: Um olhar diferenciado na educação do Adulto. Acesso em, 20.

Silveira, D. T., \& Córdova, F. P. (2009). Unidade 2-A pesquisa científica. Métodos de pesquisa, 1.

Singh, G., \& DeNoble, A. (2003). Early retirees as the next generation of entrepreneurs. Entrepreneurship theory and practice, 27(3), 207-226.

Venkataraman. (1997). O domínio distinto da pesquisa sobre empreendedorismo: A perspectiva de um editor. (J. Katz, R. Brockhaus, orgs. Avanços no Empreendedorismo, Emergência e Crescimento Firmes, vol. 3)).

Weber, P., \& Schaper, M. (2004). Understanding the grey entrepreneur. Journal of enterprising culture, 12(02), 147-164.

Zampier, M. A., \& Takahashi, A. R. W. (2011). Competências empreendedoras e processos de aprendizagem empreendedora: Modelo conceitual de pesquisa. Cadernos Ebape. BR, 9, 564-585. 